\title{
Pollution Load Capacity Assessment by Utilizing QUAL2E Modelling: A Case Study of Rambut River, Indonesia
}

\author{
Winardi Dwi Nugraha ${ }^{1,2^{*}}$, Sudharto Purnomo Hadi', Setya Budi Sasongko ${ }^{1,3}$, \\ Titik Istirokhatun ${ }^{2}$, Faradiba Faradiba², Ayu Nopita ${ }^{2}$, Dwi Siwi Handayani², \\ Fadel lqbal Muhammad ${ }^{4}$, Heru Susanto ${ }^{3}$, Mochammad Arief Budihardjo ${ }^{2}$ \\ 1 Doctoral Program of Environmental Sciences, Indonesia Department of Environmental Engineering \\ Diponegoro University, Indonesia \\ 2 Department of Environmental Engineering, Diponegoro University, Indonesia \\ 3 Department of Chemical Engineering, Diponegoro University, Indonesia \\ ${ }^{4}$ Environmental Technology Chair Group, Wageningen University \& Research, The Netherlands \\ * Corresponding author's email : winardi.dn@gmail.com
}

\begin{abstract}
Water quality modelling can be a way to determine the potential pollutant load capacity in the river water. As the number of population and intensity of activities around the river increased, it is possible that the water quality in the river will be negatively impacted. The Rambut river, which located in Pemalang and Tegal, Indonesia, has an important role as a water source in both areas. However, this demand is not accompanied by the availability of river capacity information yet. Five points from different segments along the upstream and downstream of Rambut River were assessed with the QUAL2E model. There were four different parameters in the research, e.g., BOD, fecal coliform, nitrite, and nitrate. The results showed that some segments did not comply with the minimum requirements by the local government. Additionally, the BOD and fecal coliform value were predicted to be increased in 2023 due to higher population number living near the river. The values for all parameters fluctuated between the different segments.
\end{abstract}

Keyword: QUAL2E, Rambut river, pollutant load, river capacity.

\section{INTRODUCTION}

Assesments of water quality conducted routinely in river for different water use purposes, such as irrigation, conservation and industrial usage, are an important strategy for food safety and human health. This evaluation provides important information on the status of these waterways and can help the authorized party to target the management actions (Son et al., 2020). Nowadays, the condition of all rivers in Indonesia is generally heavily polluted (Honingh et al., 2020; Kido et al., 2008; Sikder et al., 2015). Among 471 heavily polluted rivers which have been identified in 2015 and 2016, there are 17 rivers that is in a steady state where the quality remain unchanged. Besides that, there are also 211 rivers the quality of wich significantly increased, while 343 rivers were found to deteriorate
(BPS, 2017). Moreover, in Central Java province, there are 4 rivers that have been categorized as intermediately and heavily polluted, namely Bengawan Solo, Cisanggarung, Citanduy, and Progo. It is assumed that a similar pollution also happens in a river that flows near them, especially in the border of Tegal and Pemalang cities. This condition proves that most of the rivers do not meet the minimum requirements to be implemented for drinking water, water recreation, cultivation of freshwater fish, animal husbandry, crops irrigation, and other purposes (Adrian et al., 2020; Krisanti et al., 2020; Muin \& Nandiasa, 2019; Roosmini et al., 2018; Sulaeman et al., 2020).

The Rambut river is one of the rivers the quality of which has not been analyzed yet. Its upstream area is located in Tegal city, while the 
downstream area is situated in the Pemalang city, making it a geographical border for both cities. The Rambut river has the total area of $166.1 \mathrm{ki}-$ lometers square and the total length of 63,975 kilometers. This river is flowing across ten subdistricts with a total population of 722,034 people (Sugiarto et al., 2020). In addition, Tegal and Pemalang cities are considered to have high rate of population growth, directly affecting the usage intensity of the Rambut river for various purposes. The high dependency of the people towards the Rambut river is affecting the anthropogenic activity in that surrounding area, which can lead to river pollution increase. Hence, an assessment to highlight the quality of the Rambut river is needed to understand the existing condition and help to propose an effective river management strategy (Efiana et al., 2019; Faradiba et al., 2019).

In order to assess the current condition of the Rambut river, a well-recognized free-to-use modelling software called QUAL2E was used. It is able to evaluate the quality of water stream and has been implemented for various settings and parameters. This modelling software is also widely used for regulatory and policy decisionmaking due its versatility. This modelling software also has a powerful module for uncertainty analysis (Melching \& Yoon, 1996; Palmieri \& De Carvalho, 2006; Yuceer et al., 2007). Several authors stated that QUAL2E is highly suited for point sources of pollutants and limited to the rivers that have temporal variations in pollution load streamflow over a short period (Azzellino et al., 2006; Ning \& Chang, 2007).

Many researchers consider the use of QUAL2E because it can be integrated with geographical information system (GIS) which makes the analysis of pollution load more illustrative and easier to comprehend. Moreover, the use of mathematical models is predominant and becomes a useful decision-making tool for river basin management, combined with the additional data input of wastewater treatment technologies and impact estimation from discharged wastewater towards the quality of receiving streams. By considering average annual scenario and point loads input only, QUAL2E demonstrated a quite good accuracy with $20 \%$ of error percentage (Azzellino et al., 2006; Ning \& Chang, 2007).

On the basis of the existing condition of the Rambut river, this area is now mostly used as a place to discharge domestic wastewater without any proper treatment before. This is an intriguing issue that has remained unsolved until now. There are many people that still use the river as the end zone of their solid waste, grey water, and also black water. However, the existence of domestic wastewater is significantly decreasing the river quality due to physical, chemical, and microbiological process that occurs (Ling et al., 2012; Ullah et al., 2013).

This article aimed to find the quantification of pollution load capacity in the Rambut river by implementing QUAL2E. The pollution load capacity is calculated by considering the driving forces of landuse and anthropogenic activities around the river. Because of the lack of the same research in the Rambut river, this article clearly has good urgency and novelty points in identifying the river in Indonesia which is prone to be severely polluted by human. Furthermore, the result of this research is crucial to depict other river conditions in Central Java.

\section{METHODS}

Geographically, the Rambut river is located at the coordinate of $7^{\circ} 13^{\prime} 50^{\prime \prime}-6^{\circ} 52^{\prime} 15^{\prime \prime} \mathrm{S}$ and $109^{\circ} 6^{\prime} 8^{\prime \prime}-106^{\circ} 18^{\prime} 55^{\prime \prime} \mathrm{E}$, while administratively it flows through ten subdistricts, i.e. Pulosari, Moga, Bojong, Warungpring, Jatinegara, Randudongkal, Kedungbanteng, Bantarbolang, Pemalang, and Warureja. The upstream area (water spring) of this river is in a place called Balekambang, located in Suniarsih village, Bojong subdistrict, Tegal city (709'15.26" S and 109'11'19.93" E). The sample collection took place in five different points along the Rambut river (Table 1), determined according to the condition of landuse, topography, physical condition of river, and administrative border. All of these factors significantly affect the pollution load capacity due to the difference of anthropogenic activity around the river area (Sugiarto et al., 2020).

The observed parameters include BOD, fecal coliform, nitrite $\left(\mathrm{NO}_{2}\right)$, and nitrate $\left(\mathrm{NO}_{3}\right)$. There are also several supporting variables that will be used, such as river hydromorphology, pollution source inventory, and water quality. The result of mathematical modelling from QUAL2E will be compared with PP No. 82 Year 2001 as the water quality standard in Indonesia. Th e pollution load capacity of a river, especially coming from organic pollutants, can be assessed through the amount of biological oxygen demand (BOD) in the water. 
Table 1. Sampling location and coordinate

\begin{tabular}{|c|l|c|}
\hline Point & \multicolumn{1}{|c|}{ Sampling location } & \multicolumn{1}{|c|}{ Coordinate } \\
\hline 1 & $\begin{array}{l}\text { Kajenengan village, Bojong subdistrict, Tegal city. Located at an altitude } \\
\text { of } \pm 520 \text { meter above sea level }\end{array}$ & $7^{\circ} 6^{\prime} 44.37^{\prime \prime} \mathrm{S}$ and $109^{\circ} 13^{\prime} 23.76^{\prime \prime} \mathrm{E}$ \\
\hline 2 & $\begin{array}{l}\text { Jatinegara village, Jatinegara subdistrict, Tegal city. Located at an } \\
\text { altitude of } \pm 246 \text { meter above sea level }\end{array}$ & $7^{\circ} 4^{\prime} 4.17^{\prime \prime} \mathrm{S}$ and $109^{\circ} 15^{\prime} 4.69^{\prime \prime} \mathrm{E}$ \\
\hline 3 & $\begin{array}{l}\text { Kedungjati village, Warureja subdistrict, Tegal city. Located at an altitude } \\
\text { of } \pm 45 \text { meter above sea level }\end{array}$ & $6^{\circ} 59^{\prime} 18.25^{\prime \prime} \mathrm{S}$ and $109^{\circ} 18^{\prime} 31.45^{\prime \prime} \mathrm{E}$ \\
\hline 4 & $\begin{array}{l}\text { Sukareja village, Warureja subdistrict, Tegal city. Located at an altitude } \\
\text { of } \pm 13 \text { meter above sea level }\end{array}$ & $6^{\circ} 55^{\prime} 11.9^{\prime \prime} \mathrm{S}$ and $109^{\circ} 19^{\prime} 48.51^{\prime \prime} \mathrm{E}$ \\
\hline 5 & $\begin{array}{l}\text { Kedungkelor village, Warureja subdistrict, Tegal city. Located at an } \\
\text { altitude of } \pm 7 \text { meter above sea level }\end{array}$ & $6^{\circ} 52^{\prime} 20.17^{\prime \prime} \mathrm{S}$ and $109^{\circ} 20^{\prime} 35.70^{\prime \prime} \mathrm{E}$ \\
\hline
\end{tabular}

Higher amount of BOD can lead to worse pollution in the river. In addition, excressed substances from human, such as faeces, contains pathogenic bacteria like Eschericia coli, Shiglia sp, Vibrio cholera, Campylobacter jejuni, and Salmonella sp which are categorized as fecal coliform. The polution load capacity was analyzed in accordance with Appendix 1 from the Regulation of Minister of Environment and Forestry No. 1 Year 2010.

The calculation formula of potential pollutant loads from domestic sector (PPL 1) are as follows:

$$
P P L 1=\alpha \times T P \times E F \times C E R I
$$

where: PPL 1 - Potential pollutant loads (kg/day); $\alpha-$ Run-off coefficient ration; direct disposal into river $=1$, open channel $=0.5$, septic tank $=0.25$; TP - Total populations of the surrounding area (person); $E F$ - Emission factor per person $(\mathrm{kg} /$ person/day); $C E R$ - City equivalent ration; city $=1$, suburbs $=0.8125$; hinterland $=0.652$.

In turn, the calculation formula of potential pollutant loads from agricultural sector (PPL 2) are as follows:

$$
P P L 2=A x E M F
$$

where: PPL 2 - potential pollutant loads (kg/day); $A$ - land area (Ha); $E F$ - emission factor per unit area $(\mathrm{kg} / \mathrm{Ha} /$ day $)$.
The test results of each parameter were then used as a basis for determining water quality based on water class in PP No. 82 Year 2001, a national regulation from the government of Indonesia regarding water quality standard. The water classes are divided into 4 different categories, namely class I (raw water for drinking water and/ or other designation that requires same water quality), class II (water recreation infrastructure, freshwater fish cultivation, animal husbandry, crops irrigation, and/or other designation that requires same water quality), class III (freshwater fish cultivation, animal husbandry, crops irrigation, and/ or other designation that requires same water quality), class IV (crops irrigation, and/or other designation that requires same water quality).

\section{RESULTS AND DISCUSSION}

The physical characteristic containing measurement of river hydraulcs and morphology were needed as supporting data in QUAL2E. Table 2 below shows the physical characteristics data for each segment in the Rambut river. The segments were acquired by connecting the upstream area called Balekambang and all sampling points, resulting in five different segments.

According to the data below, each segment had different physical characteristic. The values

Table 2. Physical characteristics of each segments

\begin{tabular}{|c|c|c|c|c|c|c|c|}
\hline From & To & $\begin{array}{c}\text { Manning } \\
\text { coefficient } \\
(\mathrm{n})\end{array}$ & $\begin{array}{c}\text { Side slope 1 } \\
(\mathrm{m})\end{array}$ & $\begin{array}{c}\text { Side slope 2 } \\
(\mathrm{m})\end{array}$ & $\begin{array}{c}\text { Length of } \\
\text { segment } \\
\left(\mathrm{x} 10^{3} \mathrm{~m}\right)\end{array}$ & $\begin{array}{c}\text { River width } \\
(\mathrm{m})\end{array}$ & $\begin{array}{c}\text { Basic slope } \\
(\mathrm{m})\end{array}$ \\
\hline Balekambang & Point 1 & 0.040 & 0.250 & 0.250 & 13.3 & 2.33 & 0.051 \\
\hline Point 1 & Point 2 & 0.045 & 0.435 & 0.435 & 9.48 & 11.6 & 0.029 \\
\hline Point 2 & Point 3 & 0.050 & 0.204 & 0.204 & 14.4 & 15.14 & 0.014 \\
\hline Point 3 & Point 4 & 0.050 & 0.313 & 0.313 & 17.2 & 3.8 & 0.002 \\
\hline Point 4 & Point 5 & 0.060 & 0.033 & 0.033 & 10.8 & 26 & 0.001 \\
\hline
\end{tabular}


Table 3. BOD concentration from each sampling locations

\begin{tabular}{|c|c|c|c|c|c|c|}
\hline \multirow{2}{*}{ Point } & \multirow{2}{*}{$\begin{array}{l}\text { BOD } \\
(\mathrm{mg} / \mathrm{L})\end{array}$} & \multicolumn{4}{|c|}{ BOD threshold level for each water classes $(\mathrm{mg} / \mathrm{L})$} & \multirow{2}{*}{ Remarks } \\
\hline & & 1 & II & III & IV & \\
\hline 1 & $<2$ & \multirow{5}{*}{2} & \multirow{5}{*}{3} & \multirow{5}{*}{6} & \multirow{5}{*}{12} & Complied with class II \\
\hline 2 & $<2$ & & & & & Complied with class II \\
\hline 3 & $<2$ & & & & & Complied with class II \\
\hline 4 & $<2$ & & & & & Complied with class II \\
\hline 5 & $<2$ & & & & & Complied with class II \\
\hline
\end{tabular}

of Manning's coefficient (n) varied in the range of 0.040-0.060, while the basic slope values laid from 0.001 until 0.051 . The longest segment could be found between point 3 and 4 with 17,200 meters and the shortest segment was between point 1 and 2 with 9,480 meters. Additionally, there was a significant difference of river width in the first and last segment with the value of 2.33 and 26 meters, respectively.

The test results of each parameter were compared with four different water class according to PP No. 82 Year 2001. According to that rule (article 55), since the Rambut river has not been categorized in any of the water class yet, it was targeted to comply with the class II water quality standard. As shown in Table 3, the BOD concentration of all sampling points had the value below $2 \mathrm{mg} / \mathrm{L}$. It means that the Rambut river generally had low BOD value and complied with the class II water quality standard. These results indicated that the Rambut river still has significantly high oxygen content in the water. In other words, due to the low BOD concentration, the organic compounds which usually comes from domestic waste were not the main pollutant in this river.

Table 4 below demonstrated the concentration of fecal coliform from all sampling points in the Rambut river. It seems that each sampling point had significantly different amount of fecal coliform. The highest concentration was shown in sampling point 4 with 23,200 bacterial colonies per $100 \mathrm{~mL}$ of sample water, while the lowest concentration was in sampling point 1 with 100 bacterial colonies per $100 \mathrm{~mL}$ of sample water. The sampling points 1 and 5 were only ones which compled with class II water quality standard, while the others still exceed the threshold level. The high amount of fecal coliform was influenced by the domestic waste originating from residential settlements discharged into the river.

Table 5 below illustrated the nitrite concentration from each sampling location in the Rambut river. The sampling point which had the highest amount of nitrite is in point 5 with $0.063 \mathrm{mg} / 100 \mathrm{~mL}$. Besides, the lowest nitrite concentration was $0.004 \mathrm{mg} / 100 \mathrm{~mL}$, located in

Table 4. Fecal coliform concentration from each sampling locations

\begin{tabular}{|c|c|c|c|c|c|c|}
\hline \multirow{2}{*}{ Point } & \multirow{2}{*}{$\begin{array}{c}\text { Fecal coliform } \\
\text { (amount/100 mL) }\end{array}$} & \multicolumn{4}{|c|}{ Fecal coliform threshold level for each water classes (amount/100 mL) } & \multirow{2}{*}{ Remarks } \\
\hline & & I & II & III & IV & \\
\hline 1 & 100 & \multirow{5}{*}{100} & \multirow{5}{*}{1,000} & \multirow{5}{*}{2,000} & \multirow{5}{*}{2,000} & Complied with class II \\
\hline 2 & 4,800 & & & & & Uncomplied with class II \\
\hline 3 & 11,500 & & & & & Uncomplied with class II \\
\hline 4 & 23,200 & & & & & Uncomplied with class II \\
\hline 5 & 400 & & & & & Complied with class II \\
\hline
\end{tabular}

Table 5. Nitrite concentration from each sampling locations

\begin{tabular}{|c|c|c|c|c|c|c|}
\hline \multirow{2}{*}{ Point } & \multirow{2}{*}{$\begin{array}{c}\text { Nitrite } \\
(\mathrm{mg} / 100 \mathrm{~mL})\end{array}$} & \multicolumn{4}{|c|}{ Nitrite threshold level for each water classes (quantity/100 mL) } & \multirow{2}{*}{ Remarks } \\
\hline & & I & II & III & IV & \\
\hline 1 & 0.021 & \multirow{5}{*}{0.06} & \multirow{5}{*}{0.06} & \multirow{5}{*}{0.06} & \multirow{5}{*}{-} & Comply with class II \\
\hline 2 & 0.007 & & & & & Comply with class II \\
\hline 3 & 0.005 & & & & & Comply with class II \\
\hline 4 & 0.004 & & & & & Comply with class II \\
\hline 5 & 0.063 & & & & & Uncomply with class II \\
\hline
\end{tabular}


the sampling point 4 . All sampling locations had slight difference of nitrite concentration and comply with the class II water quality standard, except the sampling point 5 . According to the field investigation, $85 \%$ of the total land area around sampling point 5 was an agricultural area.

The last oberved parameter in the Rambut river was nitrate concentration, shown in Table 6 below. Similarly to the previous table, all sampling points had slight difference amount of nitrate concentration. Moreover, all sampling points complied with the class II water quality standard. The highest amount of nitrate concentration was shown in sampling point 3 , while the lowest was in sampling point 1 . After the measurement of each parameter in the Rambut river, a calculation of potential pollution load from domestic sector (PPL 1) and agricultural sector (PPL 2) was conducted.

The wastewater which entered the Rambut river originated from non-point source pollutants, such as the domestic and agricultural waste. The potential pollutant load in the Rambut river from domestic waste (Table 7) showed that the highest populated segment (from Point 4 to Point 5) had the highest value of BOD, fecal coliform, nitrite, and nitrate. On the other hand, the first segment (from Balekambang to Point 1) had the least amount of population, BOD, fecal coliform, nitrite, and nitrate. The total population number indicated the amount of domestic waste producer, which could later affect the pollution load value.

Similar trends were also shown in the potential pollution load from agricultural waste (Table 8). The segment which has the largest agricultural land area (from Point 4 to Point 5) showed the highest amount of BOD, nitrogen total, nitrite, and nitrate. In line with the population number in the domestic waste, the agricultural land area in agriculture waste in indicated as the producer of agricultural waste. Among the different parameter of polluter, the highest value was shown in the BOD.

The comparison of potential pollution load on 2019 and 2023 showed that BOD and fecal coliform had increased values, while nitrite and nitrate were decreasing (Table 9). Additionally, the highest inclining difference was shown in BOD,

Table 6. Nitrate concentration from each sampling locations

\begin{tabular}{|c|c|c|c|c|c|c|}
\hline \multirow{2}{*}{ Point } & \multirow{2}{*}{$\begin{array}{c}\text { Nitrate } \\
(\mathrm{mg} / 100 \mathrm{~mL})\end{array}$} & \multicolumn{4}{|c|}{ Nitrate threshold level for each water classes (quantity $/ 100 \mathrm{~mL}$ ) } & \multirow{2}{*}{ Remarks } \\
\hline & & I & II & III & IV & \\
\hline 1 & 0.5 & \multirow{5}{*}{10} & \multirow{5}{*}{10} & \multirow{5}{*}{20} & \multirow{5}{*}{20} & Comply class II \\
\hline 2 & 0.6 & & & & & Comply class II \\
\hline 3 & 0.9 & & & & & Comply class II \\
\hline 4 & 0.8 & & & & & Comply class II \\
\hline 5 & 0.6 & & & & & Comply class II \\
\hline
\end{tabular}

Table 7. Potential pollution load from domestic waste

\begin{tabular}{|c|c|c|c|c|c|c|}
\hline \multirow{2}{*}{ From } & \multirow{2}{*}{ To } & \multirow{2}{*}{ Total population } & \multicolumn{5}{|c|}{ Pollution load value } \\
\cline { 4 - 7 } & & & BOD (kg/day) & Fecal coliform (amount/day) & Nitrite (kg/day) & Nitrate (kg/day) \\
\hline Balekambang & Point 1 & 25,607 & 832.21 & $0.416 \times 10^{10}$ & 0.0446 & 0.223 \\
\hline Point 1 & Point 2 & 43,770 & $1,422.53$ & $0.711 \times 10^{10}$ & 0.0745 & 0.373 \\
\hline Point 2 & Point 3 & 39,981 & $1,229.40$ & $0.469 \times 10^{10}$ & 0.0679 & 0.339 \\
\hline Point 3 & Point 4 & 33,815 & $1,099.00$ & $0.549 \times 10^{10}$ & 0.0561 & 0.281 \\
\hline Point 4 & Point 5 & 48,346 & $1,571.26$ & $0.785 \times 10^{10}$ & 0.0793 & 0.396 \\
\hline
\end{tabular}

Table 8. Potential pollution load from agricultural waste

\begin{tabular}{|c|c|c|c|c|c|c|}
\hline \multirow{2}{*}{ From } & \multirow{2}{*}{ To } & \multirow{2}{*}{$\begin{array}{c}\text { Agricultural } \\
\text { land area (Ha) }\end{array}$} & \multicolumn{4}{|c|}{ Pollution load value } \\
\cline { 4 - 7 } & & & BOD (kg/day) & Nitrogen total (kg/day) & Nitrite (kg/day) & Nitrate (kg/day) \\
\hline Balekambang & Point 1 & 598.83 & 41.92 & 11.98 & 0.60 & 9.58 \\
\hline Point 1 & Point 2 & $1,069.07$ & 74.83 & 21.38 & 1.07 & 17.11 \\
\hline Point 2 & Point 3 & $1,253.17$ & 87.72 & 25.06 & 1.25 & 20.05 \\
\hline Point 3 & Point 4 & $2,470.75$ & 172.95 & 49.42 & 2.47 & 39.53 \\
\hline Point 4 & Point 5 & $4,089.90$ & 286.29 & 81.80 & 4.09 & 65.44 \\
\hline
\end{tabular}


Table 9. Total of potential pollution load on 2019 and 2023

\begin{tabular}{|c|c|c|c|c|c|c|c|c|c|}
\hline \multirow{2}{*}{ From } & \multirow{2}{*}{ To } & \multicolumn{9}{|c|}{ Pollution load value } \\
\cline { 3 - 10 } & & \multicolumn{2}{|c|}{ BOD (kg/day) } & Fecal coliform (amount x 101\%/day) & \multicolumn{2}{c|}{ Nitrite (kg/day) } & \multicolumn{2}{c|}{ Nitrate (kg/day) } \\
\cline { 3 - 10 } & 2019 & 2023 & 2019 & 2023 & 2019 & 2023 & 2019 & 2023 \\
\hline Balekambang & Point 1 & 933.99 & $1,372.3$ & 4.46 & 5.65 & 0.64 & 0.64 & 9.80 & 9.59 \\
\hline Point 1 & Point 2 & $1,565.2$ & $1,868.5$ & 7.45 & 8.97 & 1.14 & 1.13 & 17.48 & 17.07 \\
\hline Point 2 & Point 3 & $1,445.2$ & $1,701.9$ & 6.78 & 8.08 & 1.32 & 1.30 & 20.39 & 19.89 \\
\hline Point 3 & Point 4 & $1,295.1$ & $1,387.5$ & 5.61 & 6.09 & 2.53 & 2.46 & 39.81 & 38.72 \\
\hline Point 4 & Point 5 & $1,871.4$ & $1,920.1$ & 7.92 & 8.20 & 4.17 & 4.06 & 65.83 & 63.99 \\
\hline
\end{tabular}

especially from Balekambang to Point 1 . On the other hand, the nitrate from Point 4 to Point 5 had the highest declining difference. The increased value of BOD and fecal coliform was most likely caused by the higher population number in the future. The increased population number tended to increase the amount of domestic waste released into the water body, which later increased the organic compound presence (Amira et al., 2021; West \& Van Woesik, 2001).

The comparison between the results from the QUAL2E modelling and the actual field were shown in the Figure 1 below. The grapics showed that the modelled results from all parameters fluctuated. The modelled results functioned to determine the profiles of each parameter from the different segment. It could be seen that the BOD value was decreasing in the $1^{\text {st }}$ until $9^{\text {th }} \mathrm{km}$ distance and remain on the lowest level until the $17^{\text {th }} \mathrm{km}$. It was most likely to be caused by the high presence of dissolved oxygen in the river on those segments. The presence of dissolved oxygen was inversely proportional to the BOD value (Dobbins, 1964; Hutchins et al., 2021). There was a low amount of organic compound in the water, making the oxygen needed to decompose it to be lower, thus affecting the increase of dissolved oxygen (Gomolka et al., 2020; Lima Neto et al., 2007; Radwan et al., 2003). Theis was in accordance with the fecal coliform results, where the values were very low from the $1^{\text {st }}$ until $17^{\text {th }} \mathrm{km}$ distance. Furthermore, there was also a decrease in the nitrite values between the $17^{\text {th }}$ and $25^{\text {th }} \mathrm{km}$ distance, while nitrate was increasing on that segments. It showed those nitrification occurred. Nitrification was a conversion process of nitrite into nitrate due to the oxygen presence (Wang et al., 2018; Xia et al., 2017). These trends were in line with the findings of Zhang et al. (2018).

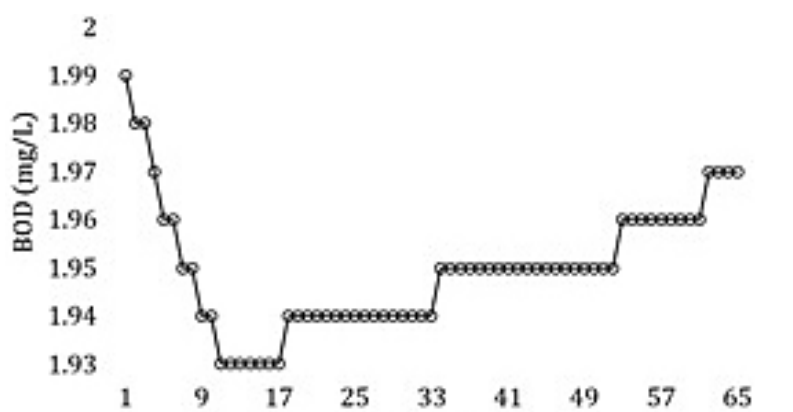

a) Distance (km)
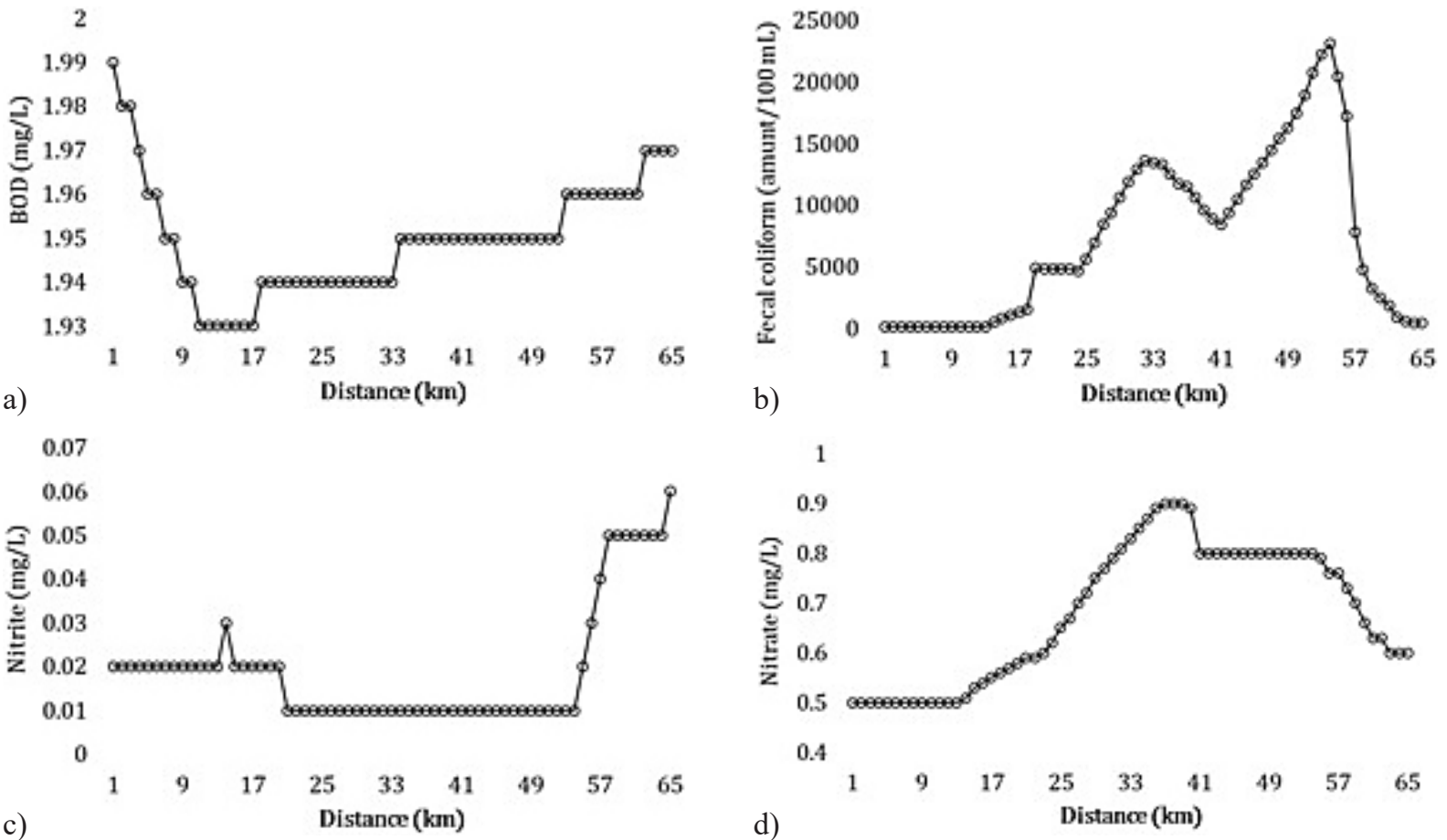

Figure 1. The results of QUAL2E modelling; (a) BOD, (b) fecal coliform, (c) nitrite, (d) nitrate 


\section{CONCLUSIONS}

This research implied that each segment in the Rambut river had different quality. Some segments complied with the class II water quality standards, while the others did not. It showed that some of the parts in the Rambut river were still available to be used as infrastructures, recreations, fisheries, or other purposes that demanded the similar quality. The water quality in Rambut River was highly affected by the domestic and agricultural waste presence. The larger population which lives near the watershed had a direct impact to the amount domestic waste discharge. Additionally, the larger agricultural area also had a direct impact towards the amount of agricultural waste that entered the water body. On the basis of projection modelling of potential pollution load in 2019 and 2023, the BOD and fecal coliform were expected to have a higher value. On the other hand, nitrite and nitrate were predicted to have a slight decrease. Moreover, the QUAL2E modelling results for all parameter on each distance showed a fluctuating trend.

\section{REFERENCES}

1. Adrian R.R., Ismail M.R., Herawati H. 2020. Spatial Distribution of Plankton in Citanduy River, Cisayong Region, Tasikmalaya, West Java. Asian Journal of Fisheries and Aquatic Research, 34-43.

2. Amira S., Soesilo T.E.B., Moersidik S.S. 2021. BOD and DO Models of Krukut River, Jakarta. IOP Conference Series: Earth and Environmental Science, 716(1), 12021.

3. Azzellino A., Salvetti R., Vismara R., Bonomo L. 2006. Combined use of the EPA-QUAL2E simulation model and factor analysis to assess the source apportionment of point and non point loads of nutrients to surface waters. Science of the Total Environment, 371(1-3), 214-222.

4. BPS S.S.L.H. 2017. Statistik Lingkungan Hidup Indonesia. Jakarta: Badan Pusat Statistik.

5. Dobbins W.E. 1964. BOD and oxygen relationships in streams. Journal of the Sanitary Engineering Division, 90(3), 53-78.

6. Efiana A.A.F., Handayani D.S., Nugraha W.D. 2019. Penentuan status mutu dan strategi pengendalian pencemaran air sungai sebagai upaya pengelolaan kualitas lingkungan (Studi Kasus: Sungai Rambut, Kabupaten Pemalang-Tegal, Jawa Tengah). Universitas Diponegoro.

7. Faradiba F., Handayani D.S., Dwi Nugraha W. 2019. Penentuan daya tampung beban pencemaran senyawa
Nitrit dan Nitrat menggunakan permodelan QUAL2E Studi Kasus: Sungai Rambut, Kabupaten PemalangTegal, Jawa Tengah. Universitas Diponegoro.

8. Gomolka Z., Krutys P., Twarog B., Zeslawska E. 2020. A new approach to spatiotemporal estimation of the river state. Journal of Process Control, 94, 125-143. https://doi.org/https://doi.org/10.1016/j. jprocont.2020.08.008

9. Honingh D., van Emmerik T., Uijttewaal W., Kardhana H., Hoes O., van de Giesen N. 2020. Urban River Water Level Increase Through Plastic Waste Accumulation at a Rack Structure. In Frontiers in Earth Science, 8, 28. https:/www.frontiersin.org/ article/10.3389/feart.2020.00028

10. Hutchins M.G., Qu Y., Charlton M.B. 2021. Successful modelling of river dissolved oxygen dynamics requires knowledge of stream channel environments. Journal of Hydrology, 603, 126991. https://doi.org/ https://doi.org/10.1016/j.jhydrol.2021.126991

11. Kido M., Yustiawati, Syawal M.S., Sulastri, Hosokawa T., Tanaka S., Saito T., Iwakuma T., Kurasaki M. 2008. Comparison of general water quality of rivers in Indonesia and Japan. Environmental Monitoring and Assessment, 156(1), 317. https:// doi.org/10.1007/s10661-008-0487-z

12. Krisanti M., Maknuun L.L.I., Anzani Y.M., Yuwono A.S., Widyastuti R., Wardiatno Y., Wulandari D. 2020. A comparative study on macroinvertebrates community in three rivers of Jawa Island, Indonesia. Aquaculture, Aquarium, Conservation \& Legislation, 13(2), 570-581.

13. Lima Neto I.E., Zhu D.Z., Rajaratnam N., Yu T., Spafford M., McEachern P. 2007. Dissolved oxygen downstream of an effluent outfall in an ice-covered river: Natural and artificial aeration. Journal of Environmental Engineering, 133(11), 1051-1060.

14. Ling T.Y., Dana M.J., Bostam S., Nyanti L. 2012. Domestic wastewater quality and pollutant loadings from urban housing areas. Iranica Journal of Energy \& Environment, 3(2), 129-133.

15. Melching C.S., Yoon C.G. 1996. Key sources of uncertainty in QUAL2E model of Passaic River. Journal of Water Resources Planning and Management, 122(2), 105-113.

16. Muin A., Nandiasa J.E. 2019. Annual flood analysis of Cisanggarung watershed in Cirebon regency. Neutron, 18(2), 42-50.

17. Ning S.K., Chang N.B. 2007. Watershed-based point sources permitting strategy and dynamic permit-trading analysis. Journal of Environmental Management, 84(4), 427-446.

18. Palmieri V., De Carvalho R.J. 2006. Qual2e model for the Corumbataí River. Ecological Modelling, 198(1-2), 269-275.

19. Radwan M., Willems P., El-Sadek A., Berlamont J. 2003. Modelling of dissolved oxygen and 
biochemical oxygen demand in river water using a detailed and a simplified model. International Journal of River Basin Management, 1(2), 97-103. https://doi.org/10.1080/15715124.2003.9635196

20. Roosmini D., Septiono M.A., Putri N.E., Shabrina H.M., Salami I.R.S., Ariesyady H.D. 2018. River water pollution condition in upper part of Brantas River and Bengawan Solo River. IOP Conference Series: Earth and Environmental Science, 106(1), 12059.

21. Sikder M., Tanaka S., Saito T., Hosokawa T., Gumiri S., Ardianor A., Uddin M., Tareq S., Shammi M., Kamal A.K., Kurasaki M. 2015. Vulnerability assessment of surface water quality with an innovative integrated multi-parameter water quality index (IMWQI). Pollution, 1(3), 333-346. https://doi. org/10.7508/pj.2015.03.010

22. Son C.T., Giang N.T.H., Thao T.P., Nui N.H., Lam N.T., Cong V.H. 2020. Assessment of Cau River water quality assessment using a combination of water quality and pollution indices. Journal of Water Supply: Research and Technology-Aqua, 69(2), 160-172.

23. Sugiarto T.W., Wulandari D.A., Atmojo P.S. 2020. Spatial Analysis of Erosion Danger Level at Rambut Watershed Area Tegal District. Journal of Development Research, 4(1), 7-11.

24. Sulaeman D., Nurruhwati I., Hasan Z., Hamdani H. 2020. Spatial Distribution of Macrozoobenthos as Bioindicators of Organic Material Pollution in the Citanduy River, Cisayong, Tasikmalaya Region, West Java, Indonesia. Asian Journal of Fisheries and Aquatic Research, 32-42.
25. Ullah Z., Khan H., Waseem A., Mahmood, Q., Farooq U. 2013. Water quality assessment of the River Kabul at Peshawar, Pakistan: industrial and urban wastewater impacts. Journal of Water Chemistry and Technology, 35(4), 170-176.

26. Wang W., Yu Z., Wu Z., Song S., Song X., Yuan Y., Cao X. 2018. Rates of nitrification and nitrate assimilation in the Changjiang River estuary and adjacent waters based on the nitrogen isotope dilution method. Continental Shelf Research, 163, 35-43. https://doi.org/https://doi.org/10.1016/j. csr.2018.04.014

27. West K., Van Woesik R. 2001. Spatial and temporal variance of river discharge on Okinawa (Japan): inferring the temporal impact on adjacent coral reefs. Marine Pollution Bulletin, 42(10), 864-872.

28. Xia X., Liu T., Yang Z., Michalski G., Liu S., Jia Z., Zhang S. 2017. Enhanced nitrogen loss from rivers through coupled nitrification-denitrification caused by suspended sediment. Science of The Total Environment, 579, 47-59. https://doi.org/https://doi. org/10.1016/j.scitotenv.2016.10.181

29. Yuceer M., Karadurmus E., Berber R. 2007. Simulation of river streams: Comparison of a new technique with QUAL2E. Mathematical and Computer Modelling, 46(1-2), 292-305.

30. Zhang Y., Shi P., Li F., Wei A., Song J., Ma J. 2018. Quantification of nitrate sources and fates in rivers in an irrigated agricultural area using environmental isotopes and a Bayesian isotope mixing model. Chemosphere, 208, 493-501. 